\title{
ENTREVISTA COM RITA JOVER-FALEIROS
}

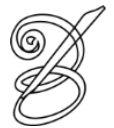 \\ Rafaela Moreira dos Santos ${ }^{1}$ \\ (Mestra em Estudos da Tradução - POSTRAD/UnB/Brasília/DF/Brasil) \\ rafaelams17@gmail.com
}

ita Jover-Faleiros é doutora em Letras (Estudos Linguísticos, Literários e
Tradutológicos em Francês) pela Universidade de São Paulo (USP) em 2010. Foi
professora adjunta da Universidade de Brasília (UnB), de 2011 a 2012, onde atuou na Licenciatura em Língua Francesa e respectiva Literatura. Atualmente é professora da UNIFESP, onde atua também na área de Língua Francesa. Desenvolve pesquisa na área de ensino da leitura e do ensino da leitura literária em contexto de formação em Francês Língua Estrangeira. É também tradutora de livros infanto-juvenis (LIJ), tendo traduzido, nos últimos anos, os livros Tantã (2009), de Marie-Aude Murail, e Dez anos e nove meses (2011), de Fred Paronuzi, em conjunto com os tradutores Heitor Ferraz de Mello e Camila Nassif.

\section{Por que traduzir LIJ?}

RITA JOVER-FALEIROS: Em primeiro lugar, acho importante assinalar o fato de haver traduzido literatura infanto- juvenil em razão dos convites feitos pela Editora SM. Assim, não se tratou de gesto espontâneo meu em razão de um interesse particular pelas obras, mas sim de demandas externas.

Nos Estudos de Tradução a discussão sobre a literatura infanto-juvenil ainda é pequena, perto da sua dimensão comercial. Nesse cenário, a senhora, enquanto tradutora de LIJ, ao perceber esta ausência de discussões no meio acadêmico, teria alguma proposta para as pesquisas de tradução de LIJ?

RITA JOVER-FALEIROS: Existem muitas questões que se colocaram para mim ao longo da tradução das duas obras, principalmente na tradução de Dez anos e nove meses. Não saberia dizer se as questões que se colocaram foram específicas à tradução da literatura infantojuvenil, mas tenderia a dizer que não. No caso específico da obra referida, houve muitas 
escolhas relativas às referências à televisão francesa, por exemplo, além de uma questão mais profunda quanto à fala do protagonista (o romance é narrado em primeira pessoa).

Do tradutor ao mercado consumidor existe uma linha de produção textual que pressupõe autoridade linguística no resultado final da tradução. Ao ler o livro publicado quais são as primeiras impressões? O tradutor se reconhece no texto?

RITA JOVER-FALEIROS: Isso depende bastante do tipo de relação que o tradutor tem (ou pode ter) com seu editor e das circunstâncias em que a tradução é feita. A tradução de Tantã foi bastante discutida em sua fase inicial até que achássemos um tom; nela eu me reconheço mais como tradutora, inclusive no tipo de leitura que estabeleci com o original. A segunda tradução é uma obra feita a muitas mãos; nela me reconheço menos.

A senhora percebe interferências no "seu" texto?

RITA JOVER-FALEIROS: Acho que a resposta acima já responde a esta pergunta; mas no diálogo com a SM e com Fabio Weintraub (editor das obras), as soluções foram sempre

198 bastante discutidas, eu não falaria em "interferências".

Essas interferências (gramaticais, semânticas, estruturais, visuais, etc.) se dão em quais níveis?

RITA JOVER-FALEIROS: Se "interferências" houver, eu diria que seria na "limpeza" de alguns galicismos. Eu me lembro bem de um comentário inicial de Fábio [editor das obras] quanto a um excesso do uso dos possessivos [frequentes em francês]. Houve muitas dúvidas e sugestões sobre as quais conversamos e elas foram de ordem semântica.

Elas são previamente comunicadas ao tradutor? É possível o tradutor rever a tradução inicial?

RITA JOVER-FALEIROS: Sim, elas foram comunicadas e foi possível rever a tradução.

Quais são as consequências dessas interferências na tradução para o tradutor?

RITA JOVER-FALEIROS: Tive experiências diferentes quanto à interferência na tradução, portanto, não posso generalizar. Posso afirmar que, quanto às experiências de tradução junto à SM, o diálogo com o editor foi algo que melhorou o resultado final por trazer outra abordagem do texto e lançar luz a aspectos do romance para os quais não havia dado talvez tanta atenção. 
Na sua concepção, existe um modelo padrão linguístico de tradução de LIJ ou existe um modelo padrão próprio de tradução para cada editora? Se sim, quais são as características desse padrão?

RITA JOVER-FALEIROS: Não sei.

Os livros Dez anos e nove meses $e$ Tantã, suas traduções de LIJ mais recentes, são exemplos de tradução final publicada cheia de interferências, a senhora percebeu isso?

RITA JOVER-FALEIROS: Acho que já está plenamente respondido.

Por fim, sob a ótica pessimista de que para o tradutor o ato de traduzir é negociar consigo mesmo as suas escolhas e, também, com as dos agentes modificadores do texto final traduzido, pode-se concluir que a tradução de LIJ, assim como qualquer outra tradução, está fadada à manipulação editorial?

RITA JOVER-FALEIROS: Eu acho que todo trabalho está fadado à negociação. A tradução é feita para ser lida não por um leitor (o tradutor), mas por uma coletividade. Eu prefiro pensar a construção de sentido(s) no ato da leitura como algo passível de ser discutido e transformado, e o que é a tradução se não um processo de leitura?

\footnotetext{
${ }^{1}$ Currículo Lattes em:<http://dgp.cnpq.br/buscaoperacional/detalheest.jsp?est=3076857792966281>.
} 